\title{
地盤と建物の動的相互作用の影響を除去した場合の建物のみの振動特性推定 \\ SYSTEM IDENTIFICATION OF. A BUILDING ALONE WITH THE EFFECT OF DYNAMIC SOIL-STRUCTURE INTERACTION ELIMINATED
}

\author{
内藤幸雄*1, 谷野達夫*2, 井口道雄*3, 北田義夫*4 \\ Yukio NAITO, Tatsuo YANO, Michio IGUCHI \\ and Yoshio KITADA
}

\begin{abstract}
High-rigidity and heavy buildings such as reactor buildings usually have large soil-structure interaction effect in its dynamic response: In such cases, spectrum ratio of the top of the building to the bottom for horizontal motion gives different result from the dynamic characteristics of the building under fixed-base condition because the effect of the rocking motion of the base is not eliminated. This paper presented a new method for such problems; applied it to a ground blast vibration, microtremors and forced vibration test results; and transfer functions of the building for fixed-base condition were obtained. The proposed method can be applied when the exciter is set at the upper part of the buildings.
\end{abstract}

\section{Keywords : System identification, Soil-structure interaction, Rocking motion, Excitation test, Forced vibration test, Microtremors}

システム同定, 地盤建屋相互作用，ロッキング動，加振試験，起振機加振，常時微動

\section{1.はじめに}

地盤剛性の割に建物の剛性が高く、基礎面積の割に重量が大きい 建物では、建物の応答特性は地盤と建物の動的相互作用に大きく影 響される場合が多い。こうした現象は、建物の変形と比較し地盤の 変形が相対的に大きくなるためと理解される。

一方本論の参考文献その他に示されたように、建物の応答からそ の振動特性を求めようとする時、相互作用の影響が大きい場合には、 建物の頂部と底部の水平方向の応答のスペクトル比を求めても、基 礎のロッキングの影響を除去できない事から基礎固定時のその建 物の振動特性とは異なった結果となる事が知られている。また、相 互作用の影響の大きい建物の上部を起振機により加振した試験結 果が、基礎固定状態あるいは地震等による下部入力時の振動特性と ビう関係づけられるかも重要である。

Luco 等は、こうした問題を扱う基本式や固有振動数、減衰定数 等を求めるいわゆるパラメトリックな手法と検討例を示し ${ }^{1) 、 ま た ~}$ 9 階建 RC 建物の起振機加振試験に適用した ${ }^{2)}$ 。基礎がスウェイ、 ロッキングする場合の影響の評価やその除去法は、運動方程式に用 いる質点の絶対座標がスウエイ、ロッキングの影響項と建物の変形 項から成る事から比較的容易に導かれ、近年では理解も広まりつつ あるが、測定により得られたロッキング動の評価法やその精度など 難しい面もあると考えられ、試験や実測結果への適用例は少ない。 筆者らはこうした問題に関し、基礎が水平動とともにロッキング
運動する場合に基礎固定時伝達関数を求める方法 ${ }^{3)}$ 、同様な条件で あるものの建物上部を起振機で加振された場合 ${ }^{4)}$ 、水平動とともに 若干のピッチング運動をする振動台上の試験体の基礎固定時伝達 関数を求めた例 ${ }^{5)}$ 等について報告してきた。前述の Luco 等の方法 と、座標系や運動方程式、固有モードの利用など出発点となる基本 事項は共通であるが、筆者らの提案手法と適用例は、伝達関数を(モ 一ド応答の絶対加速度) / (入力加速度) として表すいわゆるノン パラメトリックな手法である点に特色がある。この手法の長所とし ては、得られた伝達関数の形を見ただけでも、一般に親しまれてい る基礎が純粋に水平に動く場合の（応答絶対加速度）（基礎水平 動）による伝達関数（スペクトル比）の傾向と比較して、低振動数 域で值が 1 になるか否かあるいは共振点付近の位相変化の状況が 不自然でないかと言った検討や判断が可能な点があげられる。

本論では、相互作用の影響が大きく剛性の高い模型建物試験体の 起振機加振試験、常時微動測定、発破による地盤振動に対する応答、 等に対して提案手法を適用し、地動による慣性力に対する基礎固定 時の 1 次ピークの伝達関数、即ち基礎が純粋に水平動する下部入力 状態における 1 次ピークの伝達関数を求めた結果を示す。なお既発 表文献 3) 5)では建物の上部構造部分は水平自由度のみに単純化 して扱ったが、本論の場合には相互作用の 1 次ピークと基礎固定時 の建物の 1 次ピークが 1 対 3 程度の振動数比とシステム同定上爰 しい条件であったため、水平自由度に加え回転自由度も考虑した取

\footnotetext{
*1 鹿島技術研究所上席研究員 ·工博

*2 鹿島原子力部 副部長・工修

*3 東京理科大学理工学部建築学科 教授.工博

*4 財)原子力発鐅技術機構 部長・工博
}

Supervisory Research Engineer, Kajima Technical Research Institute, Dr. Eng. Deputy Senior Manager, Nuclear Power Department, Kajima Corporation, M. Eng. Prof., Dept. of Architectural Engineering, Faculty of Science and Engineering, Science Univ. of Tokyo, Dr. Eng.

Senior Manager, Nuclear Power Engineering Corporation, Dr. Eng. 
扱いとした。

相互作用の影響の大きい建物の基礎固定時伝達関数を精度良く 求められる事、さらに上部加振の結果が基礎固定時の特性と関連づ けられる、あるいは一方が他方に変換され得る事の実用的洒値は大 きい。例えば、建物の竣工時に起振機加振試験が実施される事が多 く、同様の試験法によるデータの蓄積や実績も多数あり、一般にこ れが試験法として最も信頼性が高いとされている。この結果から 1 次ピークのみにしろ基礎固定時伝達関数、建物のみの振動特性を抽 出できれば、竣工時（健全時）の建物の全体的な特性として、後に 高経年時や大地震後の健全性チェックの基準とでき、またこれらの 健全性のチェックは加振試験を行わなくても、地震観測記録の活用 や常時微動測定により行い得る事になる。本論の段階では損傷部位 特定の方法論や実施例は示し得ていないが、建物全体を 1 自由度系 として見た場合の剛性低下率等を検討する有用な方法論や適用例 と考え報告するものである。

\section{2. 基酜固定時伝透间数推定の方法}

(1)基本式

図 1 に示すようなスウェイ・ロッキングする剛基礎を有しまた水 平・回転自由度を有する上部構造質点系が、上部構造のある位置に 設置された起振機により水平方向に加振される場合の、上部構造の 運動方程式は下記で表される。左辺第 1 項のカッコ内は絶対座標に 関する各質点の水平と回転の加速度を表す。

$$
\left[\begin{array}{cc}
M & 0 \\
0 & I
\end{array}\right]\left(\left\{\begin{array}{l}
\ddot{x} \\
\ddot{\theta}
\end{array}\right\}+\left\{\begin{array}{c}
H \\
1
\end{array}\right\} \ddot{\theta}_{0}+\left\{\begin{array}{l}
1 \\
0
\end{array}\right\} \ddot{y}_{0}\right)+[C]\left\{\begin{array}{c}
\dot{x} \\
\dot{\theta}
\end{array}\right\}+[K]\left\{\begin{array}{l}
x \\
\theta
\end{array}\right\}=\left[\begin{array}{cc}
M & 0 \\
0 & I
\end{array}\right]\{E\} \ddot{\alpha}
$$$$
\text { ここで }
$$

$\left[\begin{array}{rr}M & 0 \\ 0 & I\end{array}\right],[C],[K]$ : 質量・慣性モーメントマトリクス、減衰 マトリクス、剛性マトリクス。左上部分が併進、右下部分が回 転自由度。

$\left\{\begin{array}{l}x \\ \theta\end{array}\right\}$ : 上部の $x$ は、基礎と共に併進、回転する座標系に関する 各質点の併進の相対変位、下部の $\theta$ は同じく相対回転角。上部 構造の変形分に相当する。

$\left\{\begin{array}{c}H \\ 1\end{array}\right\}$ : 併進に対応する自由度の $\mathrm{H}$ 洛各質点の基礎からの高さ、 回転に対応する自由度での値は 1 。

$\theta_{0}, y_{0}:$ 絶対座標に関する基礎の回転角と水平変位。

$\left\{\begin{array}{l}1 \\ 0\end{array}\right\}$ : 併進に対応する自由度での値は 1 , 回転に対応する自由 度での值はゼロ。

$\{E\}$ : 起振機設置により加振される自由度が 1 , 他はゼロの值を とるベクトル。

$\ddot{\alpha}: \ddot{\alpha}=F / m_{i}$ （起振機の加振力 $\mathrm{F}$ を設置自由度の質量 $m_{i}$ で除 したもの。)

$\ddot{\theta}_{0}$ と $\ddot{y}_{0}$ を含む項を移項すると左辺は相対変位・回転角で表され、 (2)式が得られる。

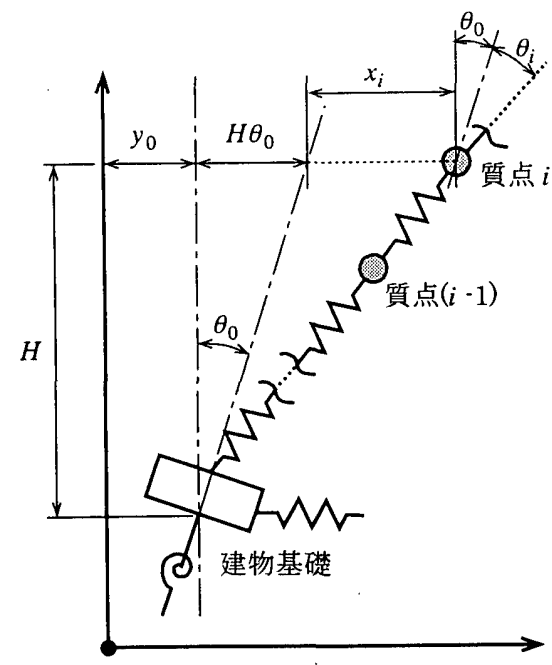

絶対座標原点

図 1 スウェイ・ロッキングモデルの記号と座標系の定義

$\left.\left[\begin{array}{cc}M & 0 \\ 0 & I\end{array}\right]\left\{\begin{array}{l}\ddot{x} \\ \ddot{\theta}\end{array}\right\}+[C]\left\{\begin{array}{l}\dot{x} \\ \dot{\theta}\end{array}\right\}+[K]\right\}\left\{\begin{array}{l}x \\ \theta\end{array}\right\}=$

- $-\left[\begin{array}{rr}M & 0 \\ 0 & I\end{array}\right]\left\{\begin{array}{l}H \\ 1\end{array}\right\} \ddot{\theta}_{0}-\left[\begin{array}{cc}M & 0 \\ 0 & I\end{array}\right]\left\{\begin{array}{l}1 \\ 0\end{array}\right\} \ddot{y}_{0}+\left[\begin{array}{cc}M & 0 \\ 0 & I\end{array}\right]\{E\} \ddot{\alpha}$

ここで $\left\{\begin{array}{l}x \\ \theta\end{array}\right\}$ を固有べクトルで表示して $\left\{\begin{array}{l}x \\ \theta\end{array}\right\}=[U]\{q\}=\sum_{s=1}^{n}\left\{{ }_{s} u\right\}_{s} q$ とし さらに(2)式の両辺に $\left\{_{s} u\right\}^{T}$ を左側から掛けると、ベクトルの直交性 から(3)式が得られる。

${ }_{s} M \cdot{ }_{s} \ddot{q}+{ }_{s} C \cdot{ }_{s} \dot{q}+{ }_{s} K \cdot{ }_{s} q=$

$\left.-\left\{s_{s} u\right\}^{T}\left[\begin{array}{cc}M & 0 \\ 0 & I\end{array}\right]\left\{\begin{array}{c}H \\ 1\end{array}\right\} \ddot{\theta}_{0}-\left\{{ }_{s} u\right\}^{T}\left[\begin{array}{cc}M & 0 \\ 0 & I\end{array}\right]\left\{\begin{array}{l}1 \\ 0\end{array}\right\} \ddot{y}_{0}+{ }_{s} u\right\}^{T}\left[\begin{array}{cc}M & 0 \\ 0 & I\end{array}\right]\{E\} \ddot{\alpha}$ ここで $\left.{ }_{s} u\right\}$ は基礎固定条件下での上部構造の $\mathrm{s}$ 次の固有べクトル、 ${ }_{s} q$ はある状態 $\left\{\begin{array}{l}x \\ \theta\end{array}\right\}$ が有する $\left\{{ }_{s} u\right\}$ 成分の大きさ、 ${ }_{s} M 、{ }_{s} C 、{ }_{s} K$ は $\mathrm{s}$ 次の広義の質量、減衰係数、ばね定数である。また(3)式右辺に現 れる $\ddot{y}_{0} 、 \ddot{\alpha} 、 \ddot{\theta}_{0}$ の係数に関連する量として以下のように ${ }_{s} \beta 、{ }_{s} \gamma$ 、 ${ }_{s} \bar{H}$ （s 次の刺激係数、起振力の影響係数、等価高さ）を定義する。

$$
\begin{aligned}
& { }_{s} \beta=\frac{\left\{{ }_{s} u\right\}^{T}\left[\begin{array}{cc}
M & 0 \\
0 & I
\end{array}\right]\left\{\begin{array}{l}
1 \\
0
\end{array}\right\}}{\left\{{ }_{s} u\right\}^{T}\left[\begin{array}{rr}
M & 0 \\
0 & I
\end{array}\right]\left\{{ }_{s} u\right\}},{ }_{s} \gamma=\frac{\left\{{ }_{s} u\right\}^{T}\left[\begin{array}{cc}
M & 0 \\
0 & I
\end{array}\right]\{E\}}{\left\{{ }_{s} u\right\}^{T}\left[\begin{array}{cc}
M & 0 \\
0 & I
\end{array}\right]\left\{{ }_{s} u\right\}} \\
& { }_{s} \bar{H}=\frac{\left\{{ }_{s} u\right\}^{T}\left[\begin{array}{cc}
M & 0 \\
0 & I
\end{array}\right]\left\{\begin{array}{l}
H \\
1
\end{array}\right\}}{\left\{{ }_{s} u\right\}^{T}\left[\begin{array}{cc}
M & 0 \\
0 & I
\end{array}\right]\left\{\begin{array}{l}
1 \\
0
\end{array}\right\}}
\end{aligned}
$$

さらに ${ }_{s} \omega=\sqrt{{ }_{s} K /{ }_{s} M} \cdot{ }_{s} h=\frac{{ }_{s} C}{2_{s} M{ }_{s} \omega}$ および ${ }_{s} q_{0}={ }_{s} q /{ }_{s} \beta$ を(3)式に代入 し以下を得る。

$$
{ }_{s} \ddot{q}_{0}+2{ }_{s} \omega_{s} h_{s} \dot{q}_{0}+{ }_{s} \omega^{2}{ }_{s} q_{0}=-{ }_{s} \bar{H} \ddot{\theta}_{0}-\ddot{y}_{0}+\frac{{ }_{s} \gamma}{s \beta} \ddot{\alpha}
$$

上式は ${ }_{s} \omega 、{ }_{s} h$ で規定される上部構造系が右辺を水平動であるとこ ろの地動として受けた場合の式と見なせる事から、この系の水平方 向の絶対加速度と地動加速度の比、すなわち伝達関数として下式が 得られる。(5)式から(6)式への変形は容易である。(6)式の分母どう しは(5)式と等しい。また $\ddot{q}_{0}$ の移項により分子どうしが得られる。 


$$
\frac{{ }_{s} \omega_{s} h_{s} \dot{q}_{0}+{ }_{s} \omega^{2}{ }_{s} q_{0}}{{ }_{s} \ddot{q}_{0}+2{ }_{s} \omega_{s} h_{s} \dot{q}_{0}{ }^{+}{ }_{s} \omega^{2}{ }_{s} q_{0}}=\frac{{ }_{s} \ddot{q}_{0}-{ }_{s} \bar{H} \ddot{\theta}_{0}-\ddot{y}_{0}+\frac{{ }_{s} \gamma}{{ }_{s} \beta} \ddot{\alpha}}{-{ }_{s} \bar{H} \ddot{\theta}_{0}-\ddot{y}_{0}+\frac{{ }_{s}^{\gamma}}{{ }_{s} \beta} \ddot{\alpha}}
$$

以上のように、地盤建屋相互作用を有する上部構造が起振機により 水平方向に加振された場合の、剛地盤上の仮想状態における上部構造 の地動に対する伝達関数を求める方法が示された。

(2)等価高さの応答によるモードの応答の代用

(6)式の ${ }_{s} \ddot{q}_{0}$ 以外の諸量は、各層重量や振動モードなど、設計図書 その他から、あるいは測定値として比較的容易に求まる。固有べク トル (振動モード) と同じ位置での測定值がそろえば測定結果から ${ }_{s} \ddot{q}_{0}$ が求まるが、多数の測定点を望めない場合も多いため、1 次モ 一ドに関し適用可能なより簡便な方法を以下に示す。簡単のため振

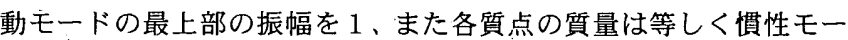

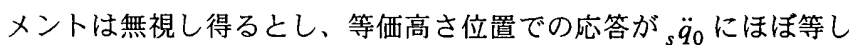
い事を示す。

i)逆三角形モードの場合

簡単のため最上部の高さを 1 とする。

$$
\begin{aligned}
& { }_{1} \beta=\frac{\int_{0}^{1} x d x}{\int_{0}^{1} x^{2} d x}=\frac{3}{2} \\
& { }_{1} \bar{H}=\frac{\int_{0}^{1} x^{2} d x}{\int_{0}^{1} x d x}=\frac{2}{3}
\end{aligned}
$$

(8)式から等価高さは $2 / 3$ となり、また逆三角形のモードである事か ら固有べクトルのこの位置の自由度の振幅は $2 / 3$ となる。さらに $\{x\}$ $\fallingdotseq\left\{{ }_{1} u\right\}_{1} \beta r_{1} q_{0}$ である事と(7)式から、1 次モードが支配的である振動 数域では等価高さにおける相対変位の振幅が ${ }_{1} q_{0}$ とほぼ等しい事が わかる。

ii) $1 / 4$ 正弦波形モードの場合

簡単のため最上部の高さを $\pi / 2$ とする。

$$
\begin{aligned}
& { }_{1} \beta=\frac{\int_{0}^{\pi / 2} \sin x d x}{\int_{0}^{\pi / 2} \sin ^{2} x d x}=\frac{4}{\pi} \\
& { }_{1} \bar{H}=\frac{\int_{0}^{\pi / 2} x \sin x d x}{\int_{0}^{\pi / 2} \sin x d x}=1
\end{aligned}
$$

(10)式から等価高さは最上部高さの $2 / \pi$ 倍であるところの 1 となり、 $\sin (1)=0.841$ である事から $\left\{{ }_{1} u\right\}_{1} \beta$ の等価高さ位置の自由度におけ る值は $(9)$ 式より $0.841 \times(4 / \pi)=1.071$ となる。従ってこの場合約
$7 \%$ の誤差を許容すれば、1 次モードが支配的である振動数域では、 等価高さにおける相対変位の振幅が ${ }_{1} q_{0}$ とほぼ等しいと言える。

以上のように、上記 i)、ii)項を通じ、等価高さの相対変位が ${ }_{1} q_{0}$ と ほぼ等しい事が分かったが、この事からまた、等価高さにおける絶 対加速度は(6)式右辺分子の ${ }_{s} \ddot{q}_{0}+{ }_{s} \vec{H} \ddot{\theta}_{0}+\ddot{y}_{0} \quad$ （ただしこの場合 $s=1 ）$ とほぼ等しいと言える。

(3)提案手法の誤差要因

以上に示したように本手法では；1)建物の基礎は剛である；2)上 部構造は基礎とのみ連結され、埋込み等、地盤との連結は無い；の 2 つを仮定している。従って、実際の建物で基礎版が変形する場合 や埋込みのある場合にはこれらは誤差が発生する要因となるため、 適用にあたり注意が必要である。

\section{3. 模型建物試験体への適用塻果}

\section{(1)試験の概要}

試験の全体計画や結果は、原子炉建屋の隣接効果試験のうちの実 地盤上試験（図 2参照）として文献 6)〜10)に示されているが、本 論ではそのうち図 3 に基本形を示した同種二棟試験体の、S 棟が単 独で建てられ埋込みの無い時期（単独非埋込み）、同じく埋込みの ある時期（単独埋込み）、 $\mathrm{N}$ 棟が付加され埋込みのある時期（隣接 埋込み）の 3 ケーズの状態に関する試験、測定結果につき検討する。 模型建物は鉄筋コンクリート製で重量約 660 ton、地上 2 階地下 1 階、 $8 \mathrm{~m} \times 8 \mathrm{~m}$ の平面で基礎底面から頂部までの高さ $10.5 \mathrm{~m}$ である。 埋込みケースでは埋込み染さは $5 \mathrm{~m}$ 、また PS 検層から得られた地 盤 Vs は以下のと㧍りである。即ち、支持地盤は $340 \mathrm{~m} / \mathrm{sec}(\mathrm{GL}-5.0 \mathrm{~m}$ $\sim 8.0 \mathrm{~m}) 、 430 \mathrm{~m} / \mathrm{sec}(\sim 11.0 \mathrm{~m}) 、 1290 \mathrm{~m} / \mathrm{sec}(\sim 25.0 \mathrm{~m}), 1590 \mathrm{~m} / \mathrm{sec}(\sim$ $52.75 \mathrm{~m})$ 、表層の周辺地盤は $160 \mathrm{~m} / \mathrm{sec}(\mathrm{GL}-0 \mathrm{~m} \sim 3.8 \mathrm{~m}) 、 320 \mathrm{~m}(\sim$ $5.0 \mathrm{~m}$ )、埋戻し土は $\mathrm{S}$ 棟単独時は $100 \mathrm{~m} / \mathrm{sec} \sim 175 \mathrm{~m} / \mathrm{sec}$ 、隣接時は $155 \mathrm{~m} / \mathrm{sec} \sim 235 \mathrm{~m} / \mathrm{sec}$ である。

起振機による加振試験は RF あるいは $1 \mathrm{~F}$ に起振機を設置し、S 棟単独時には $1 \sim 30 \mathrm{~Hz}$ 、隣接時には $2 \sim 20 \mathrm{~Hz}$ の範囲で実施された。 隣接埋込み時には、常時微動と近隣での工事の発破による振動の観 測記録がある。試験結果の代表例として、NS 方向 RF 加振時の共 振曲線を図 4 に示す。ピーク振動数は約 $7 \mathrm{~Hz} \sim 13 \mathrm{~Hz}$ にある。一方、 基礎固定とした模型建物の一本棒の曲げせん断モデルの 1 次共振 点は NS 方向が $28.32 \mathrm{~Hz} 、 \mathrm{EW}$ 方向が $31.37 \mathrm{~Hz}$ である。

(2)起振機加振試験への適用

手法や条件設定の妥当性確認のため、まず図 5 のモデルを用い
非埋込み
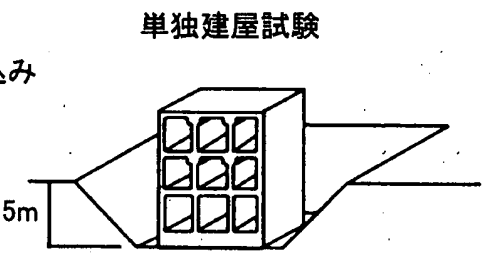

埋込み

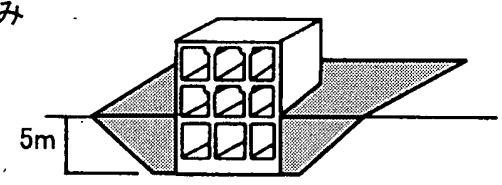

同種二棟試験

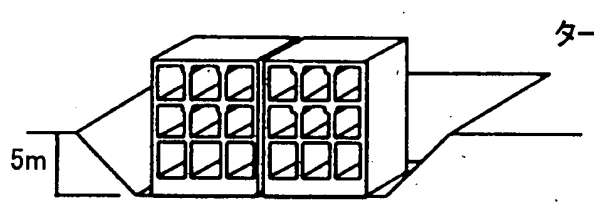

埋戻し土
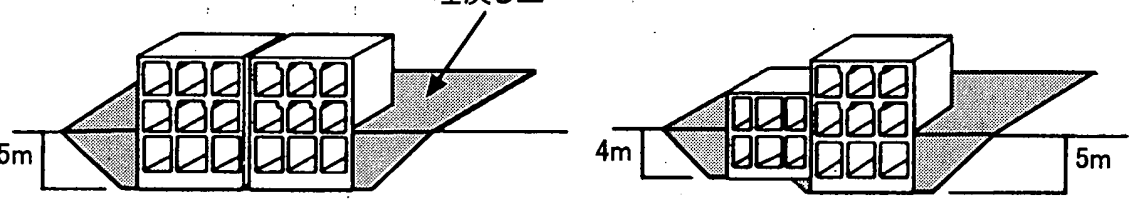

図 2 隣接効果試験（実地盤上試験）の概要 
$\mathrm{NS}$ 方向、 $1 \mathrm{~F}$ 加振のシミュレーションを行った結果に対し提案式を 適用した。ただし(6)式の ${ }_{s} \ddot{q}_{0}+{ }_{s} \bar{H} \ddot{\theta}_{0}+\ddot{y}_{0}$ の代わりに、等価高さ位置 に近い $2 \mathrm{~F}$ 応答を用いた。

等価高さは基礎底面より $8.731 \mathrm{~m} 、 2 \mathrm{~F}$ 測定点は測定結果は $7.89 \mathrm{~m}$ （センサーの高さ $14 \mathrm{~cm}$ を考慮、 $2 \mathrm{~F}$ 床上面高さは $7.75 \mathrm{~m}$ ）の位置 にある。シミュレーション結果としては $2 \mathrm{~F}$ 休上面高さを用いてい る。測定結果の $2 \mathrm{~F}$ や基礎の水平応答は両端（NS 加振の場合は東 西端） 2 点の平均として、回転は四隅の上下動から求めた。発破や
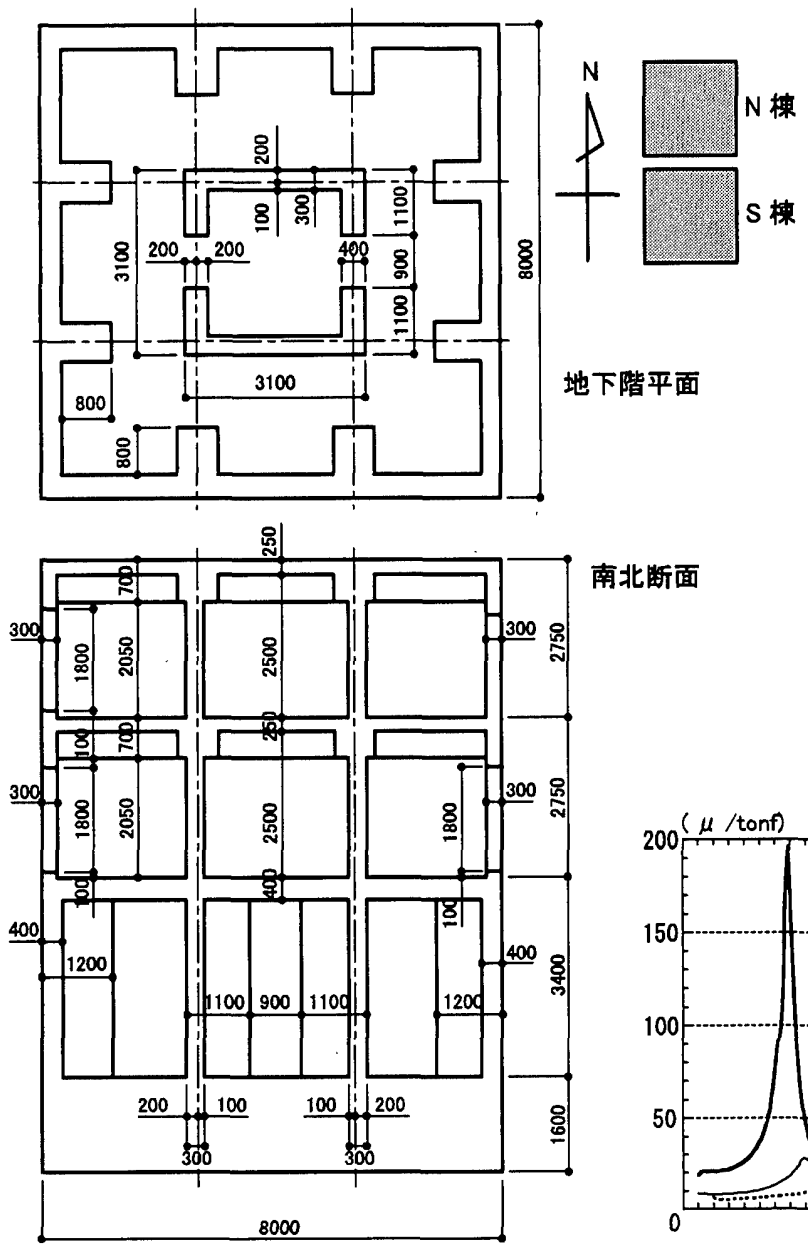

南北断面

図 3 対象とする模型建物
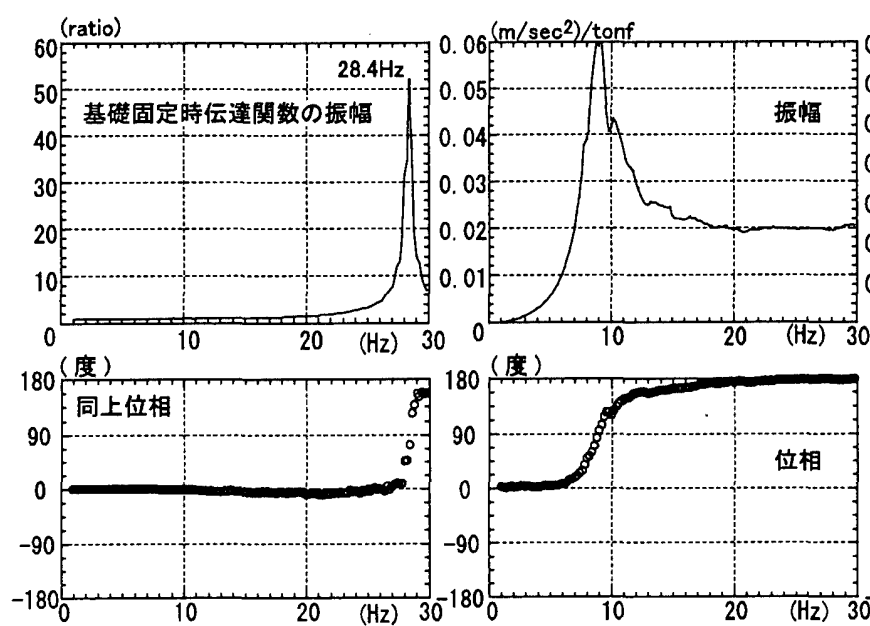

図 6 シミュレーションモデルへの 適用結果

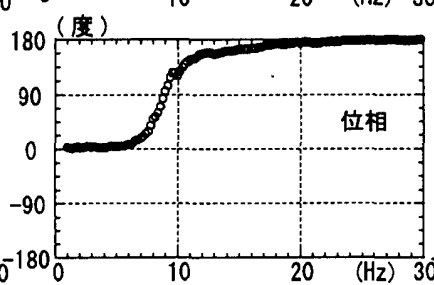

図 7 シミュレーションモデルの $2 \mathrm{~F}$ 応答

常時微動の場合も同様である。また基礎に付くスウェイ、ロッキン グばねおよびそれらの連成項は、 $1 \sim 30 \mathrm{~Hz}$ の範囲で得られている単 独埋込みの起振機加振結果から逆算した。

スウエイ、ロッキングばねを有するこのモデルによるシミュレー ション結果に上記の本論の手法を適用した結果、図6の伝達関数が 得られた。仮定した $1 \%$ の減衰定数や上記の $28.32 \mathrm{~Hz}$ と整合する結 果であり、手法の妥当性が確認されたと言える。なお参考のため、 図 7 には $2 \mathrm{~F}$ の応答、図 8 には(6)式の分母を示した。分母側がゼロ に近い值となり位相も急変する事により伝達関数のピークが得ら れている事が分かる。この事はまた、分母側の小さな誤差でも伝達

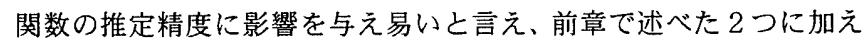
第 3 の誤差要因として、本手法を適用する上での注意事項と言える。 次に、単独非埋込みの NS 方向 RF 加振、 $1 \mathrm{~F}$ 加振の実測結果に適 用し図 9 の結果を得た。 $R F$ 加振結果からの変換では $25.2 \mathrm{~Hz} 、 1 \mathrm{~F}$ 加振では $26.6 \mathrm{~Hz}$ のピーク振動数が得られている。振動数増加に伴 い位相遅れ（正）方向ではなく進み方向への変化が見られる等ピー ク付近での位相変化が本来の基礎固定時と逆方向であったり（この 位相変化に関しては後の第 4 章で考察する)、 $1 \mathrm{~F}$ 加振では見かけの 減衰定数が大きい等の誤差的な現象も見られるが、 $10 \mathrm{~Hz}$ 付近まで の低振動数域ではほぼ伝達関数の振幅が 1、位相がゼロである事、 また位相が顕著に変化するのがピーク付近に限られる事など、信頼 すべき精度が得られていると考えられる現象も多い。結局、実測に よる非埋込み時の基礎固定条件下の伝達関数ピークとして、25〜 $26 \mathrm{~Hz}$ 程度の值が得られたと考えられる。

次に単独埋込夕時の実測結果に関し同様に行い、図 10 の結果を

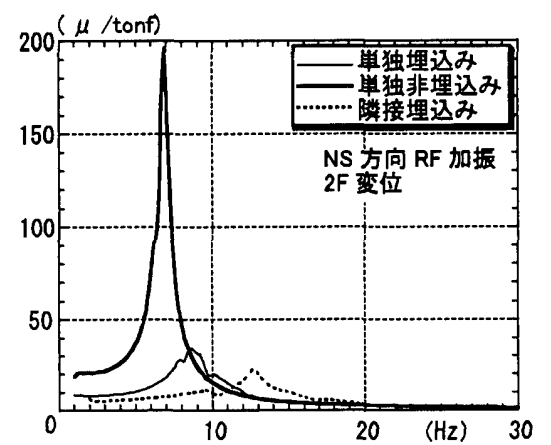

図 4 起振機による加振試験結果代表例（共振曲線）
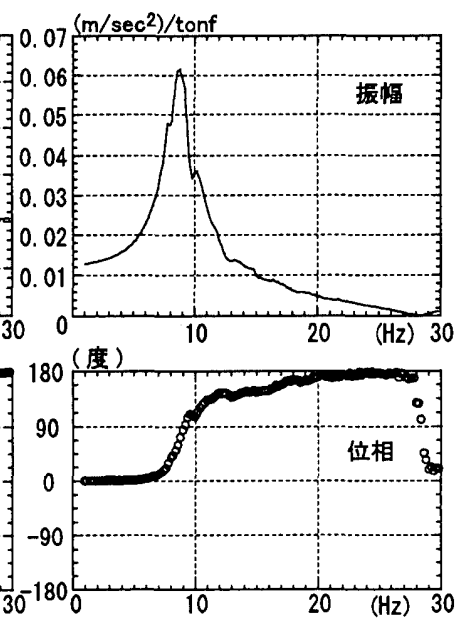

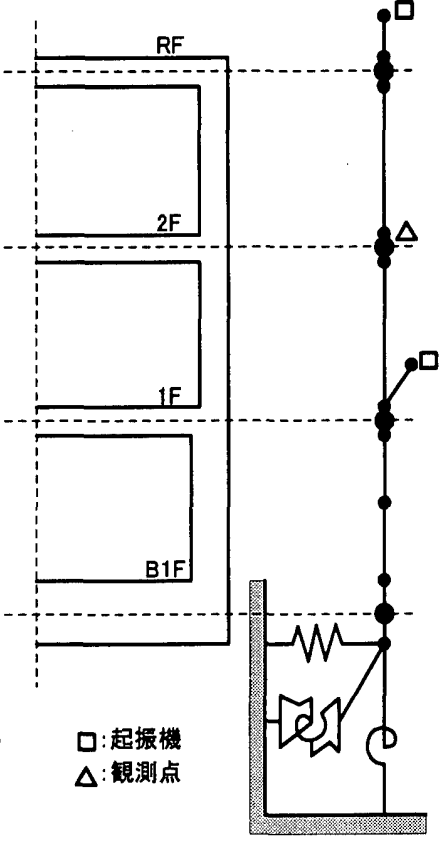

図 5 解析モデル 
得た。図 9 の $R F$ 加振で見られた $11 \mathrm{~Hz}$ 付近の振幅や位相の乱れ、 ピークにおける位相遅れの状況、見かけの減衰定数等は改善され た。ただし上記の非埋込みケースには無かった埋込み効果がシス テム同定上の誤差要因となっている。近似的には、埋込みがあり かつ基礎固定時の伝達関数を推定している事になる。 RF 加振から は $29.4 \mathrm{~Hz} 、 1 \mathrm{~F}$ 加振からは $24.0 \mathrm{~Hz}$ の結果が得られた。なお埋込み 効果による推定誤差は、上部の振幅が大きい振動形となる事から
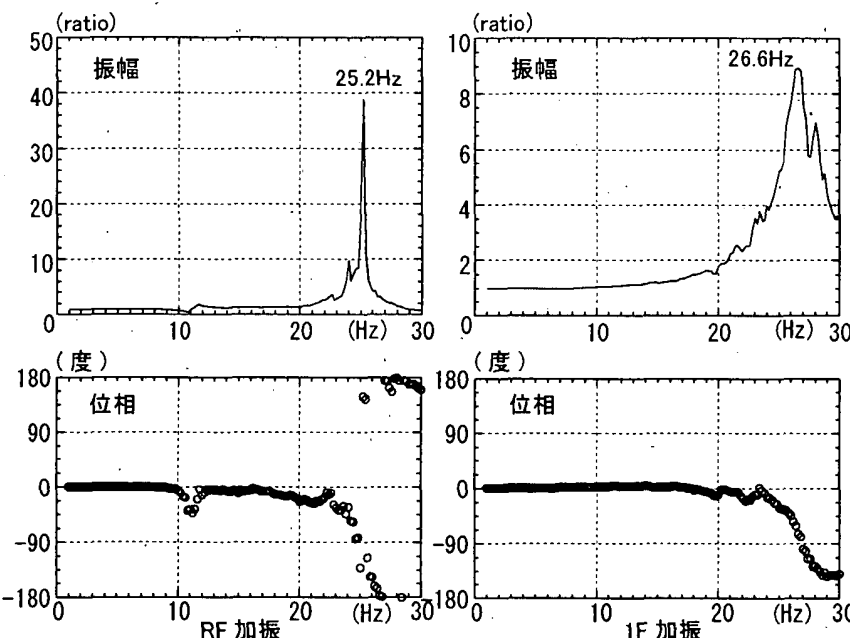

図 9 単独非埋込夕加振試験への適用結果
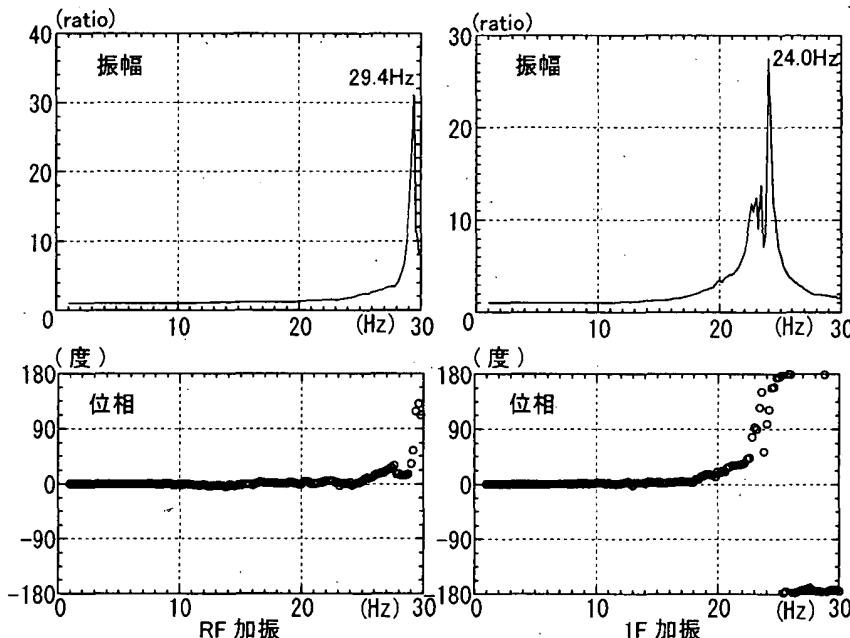

図 10 箪独埋込み加振試験への適用結架
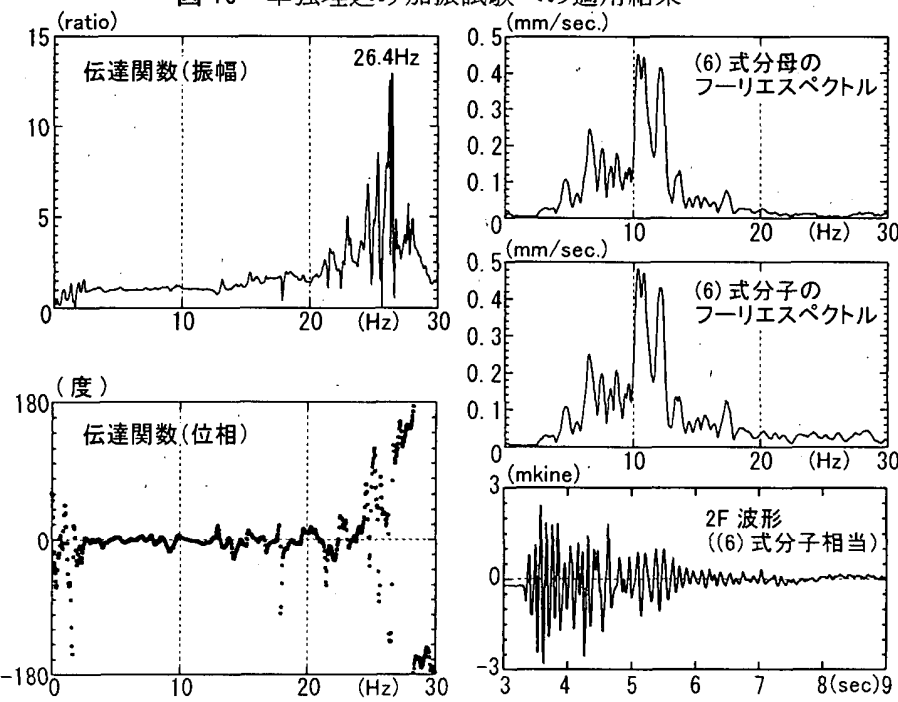

図 11 発破による振動（隣接埋込み）への適用結果
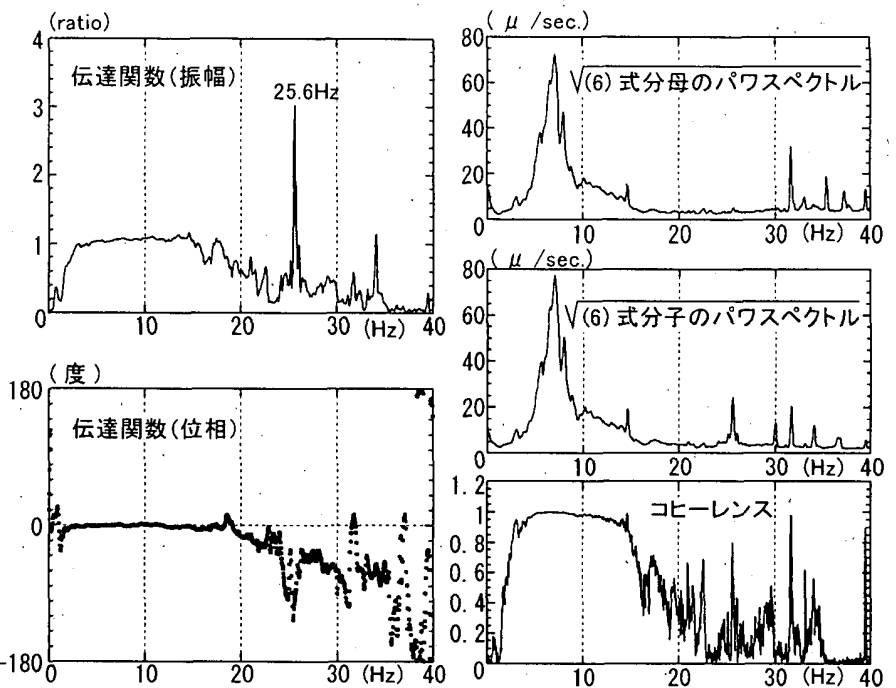

図 12 常時微動（隣接埋込み 1999 年 9 月 14 日測定）への適用結果
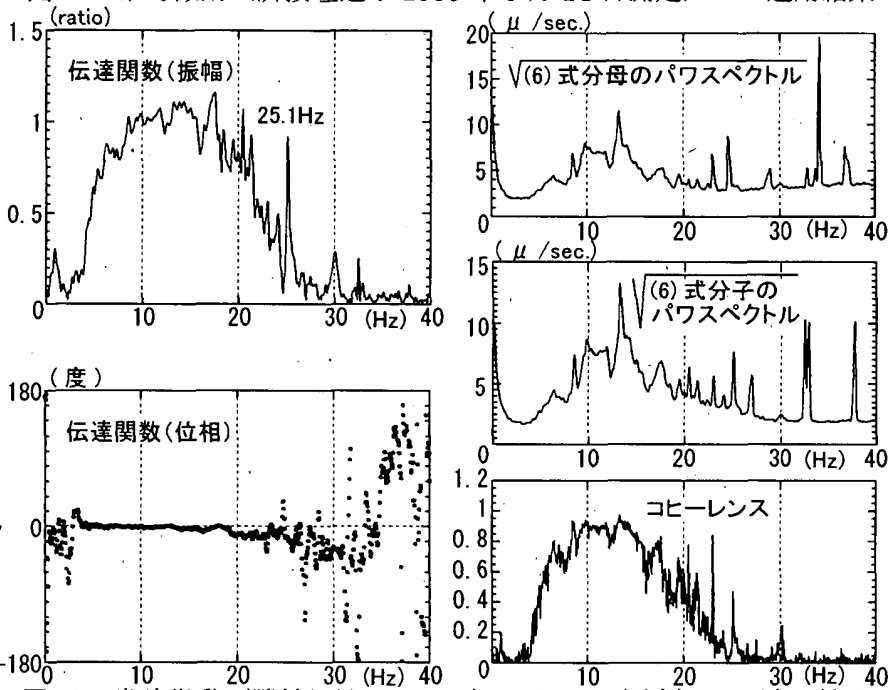

图 13 常時微動（隣接埋込み 1999 年 9 月 11 日測定) への適用結果
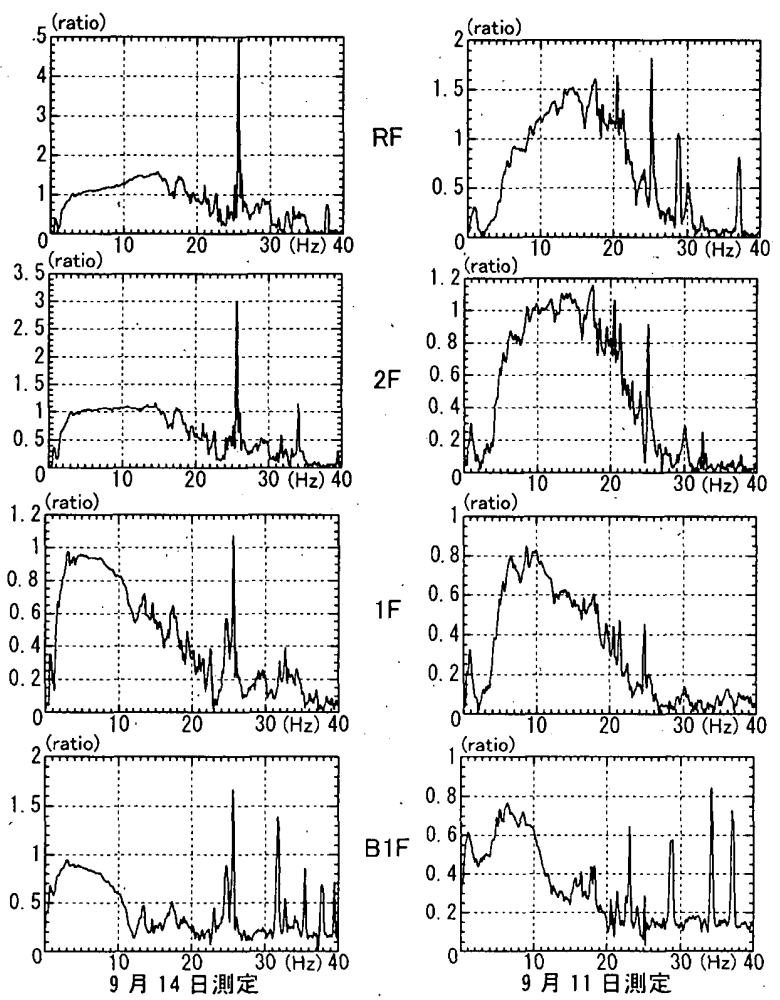

図 14 常時微動測定による各階の伝達関数（振幅） 
$\mathrm{RF}$ 加振の方が大きいと考えられる。

(3)発破による振動記録への適用

試験体から直線でほぼ $1.5 \mathrm{~km}$ の位置で発電所建設の地盤の掘削 工事が行われており、その発破による振動を、振動試験用の高感度 な計測体制で記録する事ができた。 $40 \mathrm{~Hz}$ ローパスフィルター、毎 秒 81.92 ポイントのサンプリングで 20 秒間の記録を用いた。ハニ ングウィンドウを 5 回掛けている。この結果に対し(6)式を適用した。 起振機の加振力に係わる項は値がゼロとなる。また試験体は隣接埋 込みの状態であり、単独状態時と同一の $\mathrm{S}$ 棟の NS 方向に関し分析 した。図 11 に示す伝達関数のように、 $26.4 \mathrm{~Hz}$ のピークと、この付 近での位相の変化が確認された。また $12 \mathrm{~Hz}$ 以下.の低振動数域では ほほ振幅が 1 、位相がゼロである。同図中の分母側、分子側（ $2 \mathrm{~F}$ 応答) のフーリエスペクトルを見ると、伝達関数のピークが存在す る $20 \mathrm{~Hz}$ 以上の領域ではパワーが小さい。図中にはまた、 $2 \mathrm{~F}$ 東側 測定点の波形の記録長 20 秒のうちの主要部を示した。振動試験用 の高感度な計測であったため良好な結果が得られたと考えられる。 また起振機加振のシミュレーションに関し示した図 7 、図 8 と類似 の傾向で、分母側がゼロに近い值となる事により伝達関数のピーク が得られている。

\section{(4)常時微動記録への適用}

常時微動に関しては、 $40 \mathrm{~Hz}$ ローパスフィルター、毎秒 81.92 な いし 100 ポイント、1 フレーム 20 秒間のデータで 90 回ないしは 96 回のアンサンブル平均を行い、ハニングウィンドウを 5 回掛け た。NS 方向に関し図 12、図 13 の結果が得られた。図中には、フ 一リエスペクトルに相当する、パワスペクトルの平方根も示した。 $15 \mathrm{~Hz}$ 付近以下では、ほほ伝達関数の振幅が 1 , 位相がゼロである。 ピーク振動数としては $25.6 \mathrm{~Hz}$ と $25.1 \mathrm{~Hz}$ が得られた。これらの值 は上記(2)〜(3)章の結果と比較し妥当と言える。結局、測定条件や 加振位置により若千の差やばらつきは見られるものの、起振機加振 の場合には加振位置を同じとする、常時微動や地震記録の場合には 複数回実施する、等の配慮により再現性や推定の精度が向上すると 考えられる。なお地震観測デー夕に対しても提案手法の適用を試み たが、強震計としての感度設定では $25 \sim 30 \mathrm{~Hz}$ 以上の領域にノイズ 以外の有効な成分がそしく、今回のケースでは良好な結果が得られ なかった。

\section{4. 考察}

(1)常時微動によるシステム同定に関する考察

図 12、図 13 のような伝達関数においては、近接した振動数にい くつかの見かけ上のピークが見られ、どれが真のピークか不明確な 場合も考えられる。これは、周波数成分が小さい領域においてシス テム同定を試みた事から来る結果と言える。例えば、図 11 の発破 振動時のフーリエ振幅と比較し、図 12、図 13 の常時微動時のパワ スペクトル平方根の振幅は一析小さい。また発破振動（図 11）にお いては、 $20 \mathrm{~Hz} \sim 30 \mathrm{~Hz}$ の領域で分子側のスペクトルが比較的平坦、 分母側に振幅の小さい箇所が現れる事によってピークが形成され るのに対し、常時微動ではこの振動数域で分子側、分母側にいくつ かのピークが現れる。こうした現象発生のメカニズムに関し、以下 のような検討、考察を行った。

1）図 5 のモデルに地動を与え、基礎固定時の共振点など $20 \mathrm{~Hz}$ 以
上の領域で何らかのピークが現れるか否か確認したが、基礎や上部 の応答にこうしたピークは見られなかった。従ってこれらのピーク の発生には、図 5 のモデルで表現されないメカニズム、例えば埋込み 部分地下壁からの表面波による入力などが関係していると考えた。 2）（6)式による伝達関数を、等価高さ位置に近い $2 \mathrm{~F}$ だけでなく、 他の階に関しても求め図 14 に示した。これらは厳密にはモードの 伝達関数ではないが、クロススペクトルによって各点の応答比を求 める際の規準信号として(6)式の分母側を用いたと考えれば、各階の 伝達関数の状況を把握するのに有効な手法と考えた。

3）図 14 では、先にピーク振動数とした $25.6 \mathrm{~Hz}$ （9 月 14 日測定） と $25.1 \mathrm{~Hz}$ (9月 11 日測定)のピークはほぼ各階共通に見られるが、 他は特定の測定点のみに現れる見かけ上のピークと言える。従って、 各階の伝達関数を検討する事は、ピーク振動数特定の信頼性を向上 させると言える。なお、上記の 2 つの振動数の差は、ピーク振動数 付近の測定データの周波数成分の大きさ等、与えられた条件下での、 常時微動に(6)式を適用する場合の誤差の例を表していると言える。 4） $\mathrm{B} 1 \mathrm{~F}$ のスペクトルは $20 \mathrm{~Hz}$ 以上の領域で $1 \mathrm{~F}$ よりピークが大き い傾向がある。この現象の原因は断定し難いが、 $\mathrm{B} 1 \mathrm{~F}$ 水平動を含む (6)式分母側との、アンサンプル平均によるクロススペクトルをとっ ている事から、すなわち同一信号を含む事から相関が高くなり、こ うした信号処理上の理由でピークが大きくなった事も考えられる。 5）以上述べたように、本論における常時微動への適用は、パワー が小さく $\mathrm{S} / \mathrm{N}$ 比の悪い周波数領域を対象として分析しているため やや不確定な面もあるが、図 14 のような検討も加える事により実 用的な段階に達していると言える。対象が模型試験体であったため 基礎固定時の共振点が高くその点では不利な条件であった。

(2)各ケースの振幅

起振機加振、発破、常時微動と振幅の異なる記録を用いて伝達関 数を求めている事から、各ケースの振幅が伝達関数に与える影響を 考察する。2F の応答を代表的な応答として扱う。

起振機加振の結果は加振力 1 t onf あたりの応答に換算され図 4、 図 7、図 8 で表示されているため、実振幅に戻す必要がある。基礎 固定時伝達関数の 1 次ピーク周辺の振動数範囲として $20 \mathrm{~Hz} \sim 30 \mathrm{~Hz}$ を考える。加振力は単独埋込み $1 \mathrm{~F}$ 加振は $100 \mathrm{~kg} \cdot \mathrm{cm} \times(2 \pi f)^{2} / \mathrm{s}^{2}$ 、 他は $60 \mathrm{~kg} \cdot \mathrm{cm} \times(2 \pi f)^{2} / \mathrm{s}^{2}$ であり、加振力 $1 \mathrm{tonf}$ あたりの $2 \mathrm{~F}$ 応答 は埋込み、非埋込みともこの振動数範囲で RF 加振では $4.5 \mathrm{Gal} 、 1 \mathrm{~F}$ 加振では $2 \mathrm{Gal}$ でほほ一定である（図 7 参照)。加振力（偏心モーメ

表 1 起振機加振時 $20 \mathrm{~Hz} \sim 30 \mathrm{~Hz}$ 域での $2 \mathrm{~F}$ 応答実振幅

\begin{tabular}{|c|c|c|}
\hline 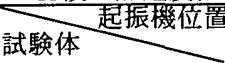 & RF加振 & $1 \mathrm{~F}$ 加振 \\
\hline 単独非埋込み & $\begin{array}{l}4 \mathrm{Gal} \sim 10 \mathrm{Gal} \\
(60 \mathrm{~kg} \cdot \mathrm{cm})\end{array}$ & $\begin{array}{l}2 \mathrm{Gal} \sim 4 \mathrm{Gal} \\
(60 \mathrm{~kg} \cdot \mathrm{cm}) \\
\end{array}$ \\
\hline 単独埋込み & 同上 & $\begin{array}{l}3 \mathrm{Gal} \sim 7 \mathrm{Gal} \\
(100 \mathrm{~kg} \cdot \mathrm{cm})\end{array}$ \\
\hline
\end{tabular}

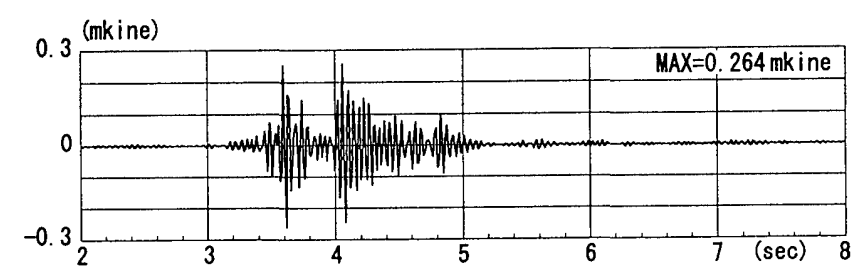

図 15 発破による $2 \mathrm{~F}$ 波形（ $(20 \mathrm{~Hz} \sim 30 \mathrm{~Hz} ）$ バンドパスフィルター 
ント $60 \mathrm{~kg} \cdot \mathrm{cm}$ で $0.967 \mathrm{tonf} \sim 2.18 \mathrm{tonf}, 100 \mathrm{~kg} \cdot \mathrm{cm}$ で $1.61 \mathrm{tonf} \sim$ $3.63 \mathrm{tonf})$ を考慮して実振幅に直すと既算值として表 1 の結果を得 る。最大で $10 \mathrm{Gal}$ である。実験時に $10 \mathrm{~Hz}$ 前後で実際に得られるピ 一クは 1 tonf 換算の共振曲線上では大きな值を示すが、この振動数 域では加振力が小さいため実振幅としては上記の10Galより小さい。 例えば図 4 の単独非埋込みケースのピークで約 4Gal である。表 1
の結果をまとめると、加振試験時 $20 \mathrm{~Hz} \sim 30 \mathrm{~Hz}$ 域における $2 \mathrm{~F}$ 応答は 2Gal〜10Gal の範囲にあると言える。

次に発破による振動時の $20 \mathrm{~Hz} \sim 30 \mathrm{~Hz}$ の成分の振幅を評価するた め、図 11.中の $2 \mathrm{~F}$ 速度波形に上記周波数域のバンドパスフィルター をかけた。結果を図 15 に示す。最大值 $0.264 \times 10^{-3} \mathrm{~cm} / \mathrm{sec}$ (mkine) を $25 \mathrm{~Hz}$ として加速度に換算すると $0.04 \mathrm{Gal}$ となる。常時微動時の
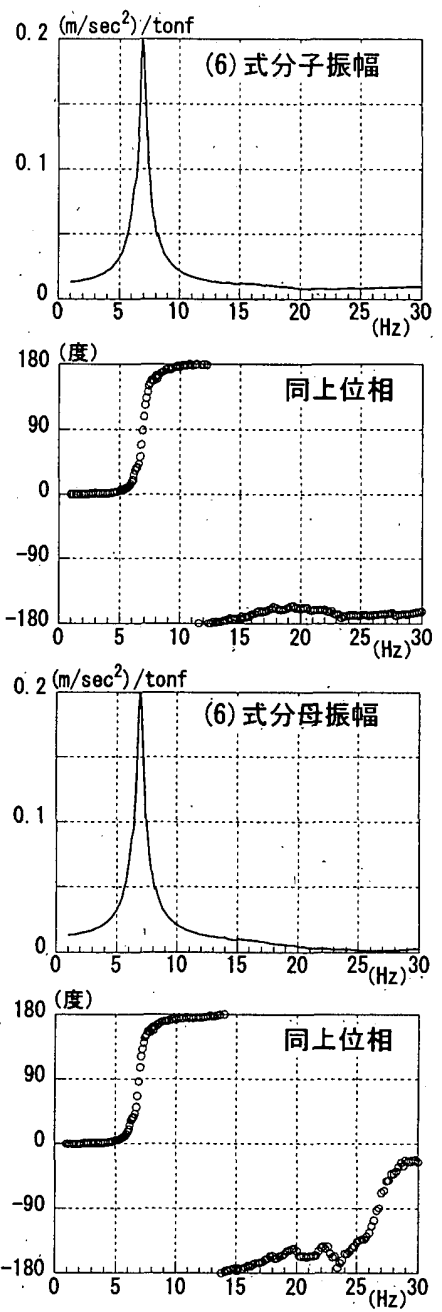

a. 単独非埋込み
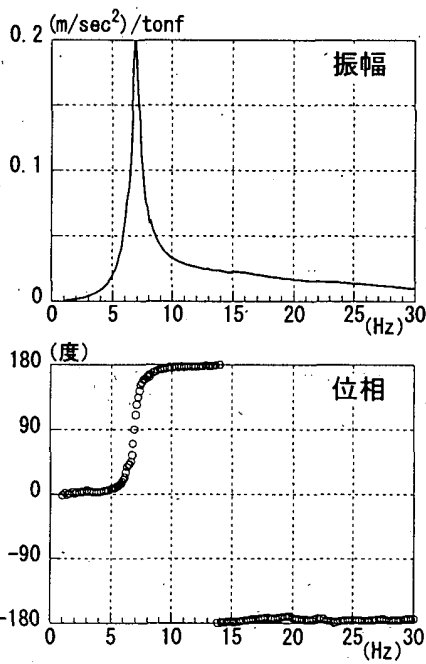

a. 単独非埋込み
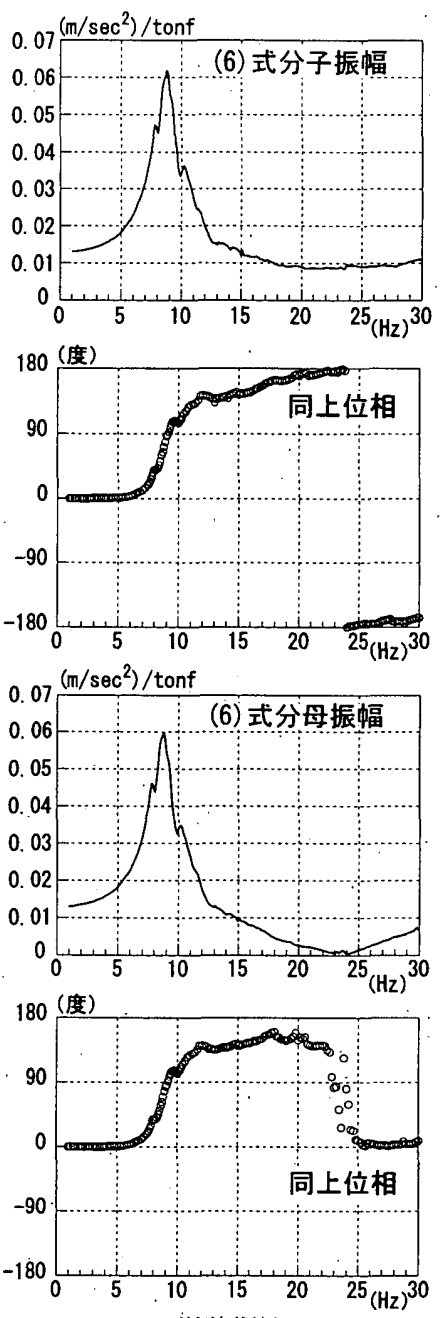

b. 単独埋込子
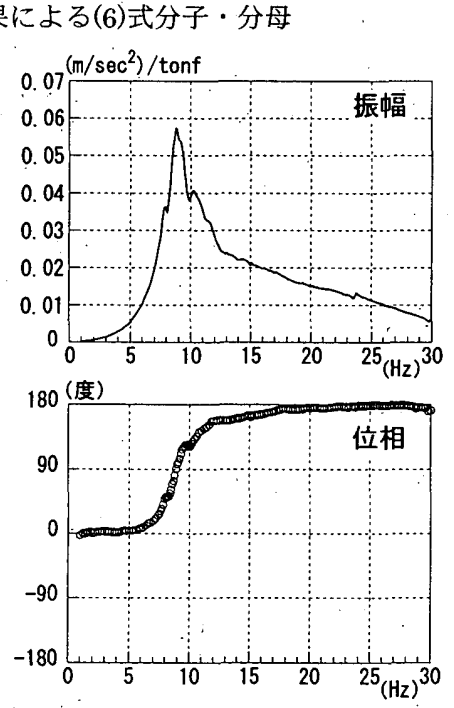

b. 単独埋込み

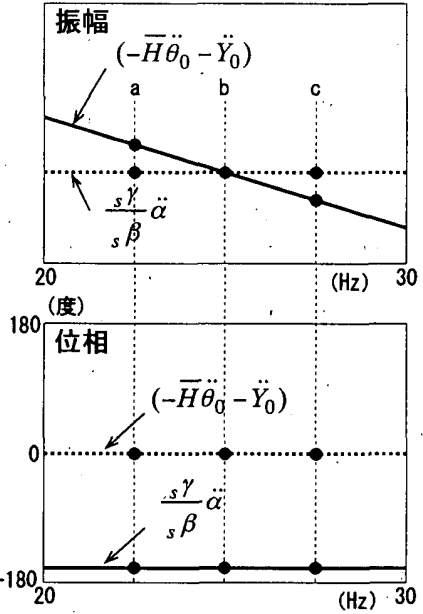

a. 振幅と位相の模式図

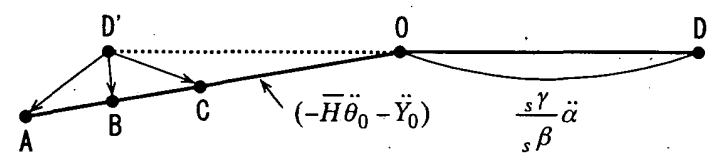

b. ベクトル表示した振幅と位相

（1）単独非埋込み
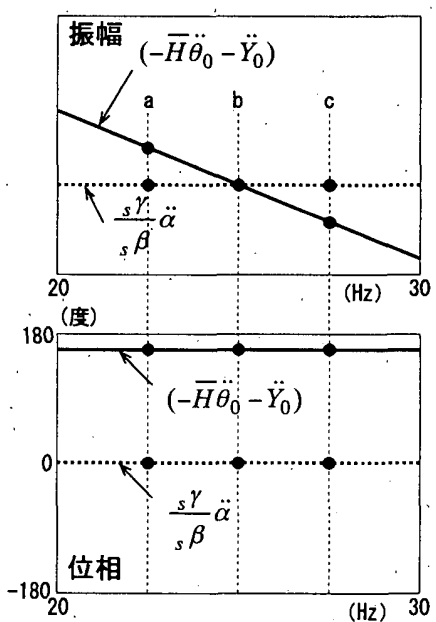

a. 振幅と位相の模式図

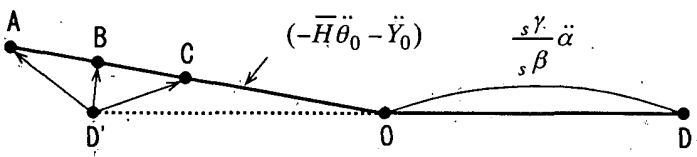

b. ベクトル表示した振幅と位相

(2) 単独埋込み

図 18 (6)式分母の位相形成の模式図

図 $171 \mathrm{~F}$ 加振結果による $(6)$ 式 $\left(-\vec{H} \ddot{\theta}_{0}-\ddot{Y}_{0}\right)$ 項 
振幅は当然発破振動より小さく、その様子は図 15 の微小振動部分 や図 11 と図 12、図 13 のスペクトルの比較からも分かる。

以上総合すると、起振機加振で $2 \mathrm{Gal} \sim 10 \mathrm{Gal}$ 、発破振動で $0.04 \mathrm{Gal}$ 、 常時微動ではそれ以下の振幅であった。コンクリート剛性の振幅依 存性による振動数の変化が顕著に現れるとは考えられない領域と 言える。従って、各同定結果の振動数の差は、主として振幅依存性 以外の要因、 2 章、 3 章で述べた 3 つの要因による誤差等によると 考えられる。

\section{（3）基礎固定時ピーク振動数付近の伝達関数の位相}

特に起振機加振結果の図 9 において、伝達関数の位相が振動数增 加に伴い負（位相進み）側へ変化する現象の原因を考察する。図 9 （単独非埋込み）と図 10 (単独埋込み）の $1 \mathrm{~F}$ 加振結果の、伝達関 数(6)式の分子と分母を図 16 に示す。 $20 \mathrm{~Hz} \sim 30 \mathrm{~Hz}$ の領域において 分子側は位相が $180\left(-180^{\circ}\right)$ 付近でほぼ一定である。一方分母 側は、基礎固定時のピーク振動数付近で、非埋込みではー $180^{\circ}$ 側 から $0^{\circ}$ 側へ変化し、埋込みでは $180^{\circ}$ 側から $0^{\circ}$ 側へ変化する。 従って（伝達関数の位相）=（分子の位相）-（分母の位相）であ る事から、つまり、分母側の位相がー $180^{\circ}$ から $0^{\circ}$ 側に変化した 事が図 9 において、伝達関数の位相が $0^{\circ}$ 側から-180 側へ変化 した事の原因と言える。次に分母側の差が出た原因を見るため、 非埋込みと埋込みの (6) 式分母側のうちの第 1 項と第 2 項の和 $\left(-\bar{H} \ddot{\theta}_{0}-\ddot{y}_{0}\right)$ と第 3 項 $\left(\frac{{ }_{s} \gamma}{{ }_{s} \beta} \ddot{\alpha}\right)$ を示す。第 3 項は定数項（振幅一 定、位相ゼロ）である。まず図 17 に実際の結果を示した。また、 図 17 の結果から図16の分母側の差が生ずるプロセスをもう少し説 明するため、図 18 に模式図を示した。a 図中の振動数が a、b、c と変化する際の振幅と位相をべクトルとしても $\mathrm{b}$ 図中に表した。 $\overrightarrow{O D^{\prime}}$ は $\overrightarrow{O D}$ (定数項) と大きさが等しく向きが反対のベクトルであ る。振動数 a、b、cにおける(6)式分母側は $\overrightarrow{D^{\prime} A} 、 \overrightarrow{D^{\prime} B} 、 \overrightarrow{D^{\prime} C}$ であ り、非埋込みケースでは $-180^{\circ}$ 方向から $-90^{\circ}$ 付近、 $0^{\circ}$ 付近と変 化するのに対し埋込みケースでは $+180^{\circ}$ 方向から $+90^{\circ}$ 付近、 $0^{\circ}$ 付近へと変化する事が分かる。図 17 に示された $20 \mathrm{~Hz} \sim 30 \mathrm{~Hz}$ 領域 におけるわずかな位相の差が、(6)式分母側の位相の差となり（図 16 参照)、これがまた図 9 、図 10 の位相の差となった事が分かっ た。

図 17 における上記の位相の差が発生した原因は特定し難いが、 わずかな位相の差がピーク付近での伝達関数の位相変化の状態を 逆転させる可能性がある事が分かり、この点は今後も注意が必要と 言える。

また常時微動から得られた伝達関数のピーク付近の位相の状況 （図 12、図 13）も、図 10、図 11のような(6)式から予想される傾
向の位相とは異なっている。これに関しては、この周波数域でパワ 一の小さい記録を用いた事から来る現象と考えるが、明確な結果を 得るためには、他の構造物への適用例が増え、今後データが蓄積さ れる事を待つ必要があると考えられる。

\section{5. まとめ}

地盤建屋相互作用の影響の大きい振動データから基礎固定時の 建物の伝達関数を求める方法を示し、シミュレーションモデルや模 型試験体に関する実測結果に適用し有効性を確認した。大地震後や 高経年時の建物の健全性チェックに使用し得る手法と考えられる。 また今後の課題として、実際の建物への適用や埋込み効果の影響の 定量的評価を行う事が考えられる。なお本論は、財団法人原子力発 電技術機構が経済産業省より委託を受けて実施した耐震安全解析 コード改良試験「原子炬建屋の隣接効果試験」の内容の一部である。

\section{参考文献}

1) Luco, J. E. : Soil-structure Interaction and Identification of Structural Models, Proc. 2nd ASCE Conf. on Civil Engng. and Nuclear Power, Vol. 2, pp. 10/1/1-10/1/31, 1980. 9

2) Luco, J. E., Wong, H.L., and Trifunac, M. D. : Soil-structure Interaction Effects on Forced Vibration Tests, Report 86.05, Dept. of Civil Engineering, Univ. So. Calif., Los Angeles, Calif., 1986. 9

3）石橋敏久, 内藤幸雄 : 基礎のロッキングを考慮した構造物の伝達関数評価 法の検討，鹿島技術研究所年報第 42 号，pp. 199-203, 1994.10

4) Naito, Y., Sato, K., Uchiyama, S., Masuda, K., Iwamoto, K. : System Identification of Structural Characteristics for Ground Motion using Forced Vibration Test Results, Transactions of the 14th International Conference on Structural Mechanics in Reactor Technology (SMiRT 14) K05/1, pp. $185-192,1997.8$

5）内藤幸雄, 片山洋, 三枝努, 早川崇, 鶴巻静雄, 秋山宏, 瀧口克己：コン クリート製原子炬格納容器酎震実証試験 (II. RCCV 耐震実証試験) その 8 . ピッチングの影蠁除去法と減衰定数評価法, 日本建築学会大会学術講演梗概 集 21593, pp. 1185-1186, 1999.9

6) Yano, T., Kitada, Y., Iguchi, M., Hirotani, T., Yoshida, K. : Model Test on Dynamic Cross Interaction of Adjacent Buildings in Nuclear Power Plants, Proceedings, 12WCEE, \#0477, 2000. 1

7）鈴木篤，北田義夫，井口道雄，谷野達夫，内藤幸雄 : 地震観测にもとづく 構造物の接効果の検討，日本建築学会大会学術講演梗概集 $21169, p p .337$ $-338,2000.9$

8) Kitada, Y., Iguchi, M., Fukuwa, N., Kusakabe, K., Nishikawa, T., Shinozaki, Y. : Model Test on Dynamic Cross Interaction of Adjacent Buildings in Nuclear Power Plants-Overview and Outline of Earthquake Observation in the Field Test, Transactions, SMiRT 16, Session K, \#1272, 2001. 8

9) Naito, Y., Yano, T., Suzuki, A., Kurita, S., Kazama, M. : Model Test on Dynamic Cross Interaction of Adjacent Buildings in Nuclear Power Plants-Field Test, Transactions, SMiRT 16, Session K, \#1138, 2001. 8

10）鈴木篤，北田義夫，井口道雄，日下部馨，西川孝夫，内藤幸雄，篠崎裙 三, 福和伸夫, 谷野達夫, 吉田長行, 栗田折, 田守伸一郎 : 隣接構造物の動 的相互作用に関する試験（その $1 \sim$ そ 3 ), 日本建築学会大会学術講演梗 概集 21476-21478,pp. 951-956, 2001.9 